\title{
The Modernity of Yoga Powers in Colonial India
}

If Ramalinga's 1867 verses emphasized his place in a lineage of Shaiva bhakti poetsaints, poems published after his death led his followers and others to include him among the antinomian Tamil siddhas. The publication of the sixth Tirumurai in 1885 , more than a decade after his death, was to significantly reconfigure his literary corpus and his Shaiva legacy. These verses were explicitly critical of cornerstones of established Shaivism, such as ritual practices, caste hierarchies, and textual elitism. The critical spirit of these poems, along with Ramalinga's claim to wield supernatural powers, contributed to his reputation as siddha, a poet who juxtaposed social critiques with miraculous claims. In these poems, Ramalinga was not seeking Shaiva respectability and, indeed, many aspects of their message is hardly recognizable as Shaiva. In this chapter I focus on these poems, and on this Ramalinga-Ramalinga the siddha.

It is as siddha that Ramalinga's status as a modern religious leader seems to be most ambiguous. In the poems of the sixth Tirumurai, Ramalinga ridicules the Vedas and Agamas; calls for the abolishing of caste; and promotes a community that is open to all, regardless of caste or class. He also speaks openly of his acquisition of supernatural powers, and he promises these powers and eternal life to anyone who joins him. If his egalitarianism appears to align with dominant conceptions of modernity, his promotion of the miraculous is contrary to those rationalizing processes that are central to those dominant conceptions.

This ambiguity lies at the heart of this chapter. I argue that the apparent contrast between a "modern" value like egalitarianism and a "traditional" belief in the miraculous only arises as a problem when we attempt to universalize Western modernity. An analysis of Ramalinga's project in terms of Western modernity may 
lead us to try to disentangle his project into "traditional" and "modern" features, assigning the miraculous to past tradition and his egalitarianism to modern forces, perhaps mediated by missionary or colonial agents. ${ }^{1}$ I reject that approach for at least two reasons. First, the diversity of influences on Ramalinga-Shaiva, cosmopolitan, Western, missionary-are so complex, intertwined, and ambiguous, that it is impossible to untangle them in a clear way. Second, Ramalinga's promotion of the miraculous and egalitarianism were not two features that sat uncomfortably together. Instead, his invocation of the miraculous was a primary strategy through which he built his community and advanced his egalitarian teachings. He democratized the miraculous, promising extraordinary powers and immortality to a range of worshipers, regardless of caste or class.

This chapter argues that the combination of Ramalinga's egalitarianism and his promise of the extraordinary resulted in a powerful expression of enchanted modernity that was salient, even transformative, in his own time, and that combination continues to shape Hindu traditions today. As Peter Pels has noted, although scholars have "acknowledged the existence of magic in modernity, this acknowledgement was rarely accompanied by theoretical statements that reflected on the ways in which magic belongs to modernity." I consider Ramalinga's promotion of miracles to "belong" to modernity, because it presented an innovative vision for thinking about liberation, ethics, community, and society, a vision that responded to his changing world. His formulation drew from a range of institutions and ideologies around him, and the changes he initiated remain influential in Tamil Shaiva discourse. My position requires us to understand his modernity in ways that do not emphasize the characteristics of a Western rationalism, and here he differs significantly from cosmopolitan reform figures who actively sought to adhere to the standards of Western modernity. It is precisely because Ramalinga did not adhere to Western notions of rationality that he has been excluded in narratives of Hindu modernization. By including Ramalinga's teachings in narratives of religious change in nineteenth-century South Asia, I advance a more pluralistic understanding of the emergence of Hindu modernity.

\section{HISTORICIZING THE MIRACLES OF YOGA}

The most popular accounts of yogic power among Tamil-speaking communities are narratives of the exploits of the siddhas. Tamil siddhas are Shaiva yogis and authors who claim to have gained extraordinary powers, siddhis, through their practice of austerities and also in their consumption of powerful medicines. ${ }^{3}$ The Tamil siddhas are noteworthy not only for their possession of magical powers, but also for their trenchant critiques of everyday Hindu practices, such as the worship of icons of the gods in temples, mediation of brahman priests in rituals, and hierarchies of caste. ${ }^{4}$ Their writings have often been shunned by established 
Shaiva institutions, and until recently they have been relegated to the margins of Tamil religiosity.

In 1860 s South Asia, there were various, and contradictory, ways that a number of groups and authors viewed Tamil siddhas and yogis, more broadly. Works of the Tamil siddhas were among the most frequent to appear in the early decades of Tamil book publishing, indicating that there was keen interest in siddha writings among Tamil readers. By 1870 , many siddha texts had found their way into print, including works attributed to Agastya, Bhogar, Akappey Cittar, Konganar, Katuveli Cittar, Pulippani, Teraiyar, Civavakkiyar, and Uromarisi. These works included critiques of orthodox ritual and caste, and they also focused on a number of areas of practice such as astrology, medicine, alchemy, mantras, and other magical ritual formulae. ${ }^{5}$ This period saw not just the publication of siddha texts but also the composition of new siddha works. In his study of the siddha Bhogar's 7,0oo-verse text, Layne Little posits that the work was at least partly composed just prior to its publication in 1888 , noting that it mentions technological innovations such as parachutes and trains, refers to Rome and China, and includes English words. ${ }^{6}$ It seems clear that many Tamils were editing, producing, and reading works attributed to the siddhas in the period of Ramalinga's activity.

Some European Orientalists and Christian missionaries praised siddha works as examples of Hindu monotheism, and they extolled the common anti-ritual sentiment expressed in these writings as an indigenous critique of idol worship and priestly corruption. In an 1871 work, Charles E. Gover described South Indian Hinduism as having an early "authentic" layer that was monotheistic, against caste, and looked very much like Christianity. According to Gover, this early "folk" layer was later corrupted by brahman priests who introduced superstitious beliefs and idol worship. Gover asserted that the Tamil siddhas exemplify this early tradition, expressing the purity of South India Hinduism in writings that were against caste, idol worship, and ritual. ${ }^{7}$ This perception that the siddhas articulated a sort of proto-Christian Hinduism may have led to the popularity of siddha works among Tamil Christians. In an 1839 report on the contents of the Mackenzie Manuscripts, the Rev. William Taylor provided some notes about a manuscript of siddha Civavakkiyar's poems. Taylor remarks that because the work strongly criticizes brahmanic ritual, "I was told some years ago that the ascetics (or Pandarams) [brahman priests] of the Saiva class, seek after copies of this poem with avidity, and uniformly destroy every copy they find. It is by consequence rather scarce; and chiefly preserved by native Christians." The social and ritual critiques of the siddhas aligned with Protestant critiques of Hindu worship and won Christian admirers.

If Christians and some Hindu readers were propagating the texts and teachings of the siddhas, many Hindu leaders in the nineteenth century disparaged siddhas or yogis as superstitious embarrassments to an essentially rational tradition. 
Dayananda Saraswati extolled the Vedas as works that eschewed ritual and promoted monotheism and a sense of reason. In his Satyarth Prakash, Saraswati celebrates the principles that Vedic sages developed through "refined reason."9 Saraswati speaks out strongly against Hindu traditions that he viewed as contrary to reason, such as astrology, alchemy, and healing. "As regards small pox goddess [sic], incantations, charms, mystic symbols and other magical devices, suffice it to say that they are all superstition." ${ }^{10} \mathrm{He}$ also objects to a range of important ritual practices, for example, shraddha funerary rites, which are "against the teaching of the Vedas and the reason [sic]." Reformers like Saraswati singled out for critique practices that had no textual sanction, practices that were not coincidentally often popular among lower-caste Hindus.

Cosmopolitan reformers like Saraswati employed a specific notion of rationality that they drew from Western discourses. Brian Hatcher links Rammohan Roy's sense of rationality to European views, noting that Roy "was among the first to creatively engage both the Upanishads and the classical tradition of Advaita Vedānta associated with Śañkarācārya (ca. eighth century C.E.) from a perspective of Enlightenment rationality." ${ }^{12}$ As Robert Yelle points out, this sense of "rationality," which was monotheistic and ritually minimalistic, was largely based on Protestant traditions. "While drawing on indigenous sources, Rammohan Roy's and Dayananda Saraswati's views appear to owe more to their encounter with Protestantism and their desire to reformulate Hinduism as a more rational, simple form of devotion, suitable for modern modes of living." ${ }^{13}$ The rationality of these reform leaders was one that replayed Protestant critiques of Catholicism, rejecting the worship of images, polytheism, and the plethora of rituals that make up everyday Hindu practice.

Saraswati's critiques of Hindu traditions extended to the attribution of extraordinary powers, siddhis, to accomplished sages and yogis. ${ }^{14}$ In Satyarth Prakash, he defines ignorance in the following way: "To believe the . . . decaying body to be permanent ... with the view to keep it on for ever by means of psychic energy or the influence of Yoga . . . is the first phase of ignorance." ${ }^{15}$ He rejects the possibility that human beings can possess extraordinary powers or attain immortality, asserting that there has never been a person "who could change the order of nature set up by God. There will never be such a person. . . . No yogi or master of occult powers can alter it [God's law]." ${ }^{16}$ Saraswati also recoils at the tantric links to yogic powers. ${ }^{17} \mathrm{He}$ derides tantric priests who announce their great power, perform murder rituals to kill an enemy, but then secretly hire men to poison their victim. ${ }^{18}$ Saraswati rejects the miracles of yoga as contrary to reason and for their tantric associations.

For Saraswati, the powers are tools of deceit that dishonest people use to exploit the gullibility of the uneducated masses. His objections were partly based on class and caste prejudices. Like other reformers, he worked to establish a Hinduism based on elite, Sanskrit works, and his criticisms were directed toward practices 
and beliefs prevalent among the lower classes and castes. This elitist aspect of the modernizing project of Hindu reform parallels those in Europe, as described by Michael Saler. "From the eighteenth through the twenty-first centuries, elites have tended to associate wonders with the disreputable no less than the irrational, and during this period the self-conscious celebration of wonders and marvels has gravitated from elite to 'popular' and then 'mass' culture."19 Thus, Saraswati disparages Kabir, a low-caste Hindu poet-saint whose popularity crosses caste boundaries. For Saraswati, Kabir was a fraud who deceived ignorant people, especially from lower castes, and who criticized the Vedas after his efforts to gain a Vedic education were rebuffed by brahman pandits. ${ }^{20}$ Swaminarayan, the founder of a nineteenth-century devotional Hindu community that remains popular today, claimed miraculous powers in order to swindle "ignorant, simple and artless people." Thus, we must see in this reform critique of siddhis not a process of objective rationalization, but the employment of a Protestant notion of rationality to advance a high-caste vision of Hinduism by attacking practices that were common across classes and castes.

It is the rationalizing projects of reform figures like Dayananda Saraswati and Arumuga Navalar that have received the most attention by scholars of nineteenthcentury Hinduism. Ramalinga's project thus presents us with a "minority history" in the sense that Dipesh Chakrabarty describes it. "Such 'minor' pasts are those experiences of the past that always have to be assigned to an 'inferior' or 'marginal' position as they are translated into the academic historian's language." These are pasts "that the 'rationality' of the historian's methods necessarily makes 'minor' or 'inferior,' as something 'non-rational' in the course of, and as a result of, its own operation." For Chakrabarty, these histories offer the potential to challenge those dominant histories, and thus to "cast doubt on the 'major." ${ }^{22}$

The "major" history that concerns me here is the scholarly narrative of Hindu innovation and modernization in the nineteenth century, with its almost exclusive focus on cosmopolitan reform expressions of Hinduism that adhered to Western criteria of rationality. As we have seen, Yelle noted that Roy and Dayananda utilized Protestant rationality to produce a Hinduism "suitable for modern modes of living." For Hatcher, Roy employed Enlightenment rationality to fashion a Hinduism that "fit the spiritual needs of his generation. Rammohan's efforts during the $1820 \mathrm{~s}$ to articulate a rational and modern form of Vedantic theism culminated in the creation of the Brāhmo Samāj in 1828, an organization and later a broad movement that would have immense influence across India." As Hatcher points out, though, this influence was largely limited to a bourgeois class of Hindus. ${ }^{23}$ I do not want to unfairly critique Hatcher's and Yelle's outstanding works, both of which are important contributions to the study of religion in colonial India. I simply want to suggest that there were other projects to reshape Hinduism along lines that did not accord with Protestant rationality, but which nevertheless "fit the spiritual needs" of the nineteenth century. Ramalinga's promotion of the miraculous was one such 
project, and I argue here that it was as modern as those reform traditions that opposed him.

\section{RAMALINGA'S ACQUISITION OF THE SIDDHIS}

Ramalinga and his followers deliberated carefully over the sort of public persona they would project with the publication of verses in 1867. The editor of the 1867 work, Toluvur Velayuda Mudaliyar, pointedly noted that he possessed many of Ramalinga's poems that he would withhold from publication. He allocated these poems to a sixth chapter to be published in the future. "With regard to the sixth Tirumurai, which the great one [Ramalinga] gave us through his grace - there are those who decided that fate has determined that is not yet time for their publication. Enough said. I'll now describe the publication of the other five Murai." ${ }^{24}$ Mudaliyar's statement suggests that there was debate among Ramalinga's followers about whether to publish these more radical verses. By including only the most conventional poems in the 1867 publication, Ramalinga's followers chose to present him as a respectable Shaiva saint rather than a controversial siddha poet.

This sixth book was first published nearly twenty years later in $1885 .{ }^{25}$ It is the longest of all six sections, with 2,551 verses of a total of 5,817 verses in all six sections, or about $44 \%$ of his verse writings. ${ }^{26}$ This indicates that far from being marginal or secondary to Ramalinga's thinking and teaching, these radical ideas were central to his vision of a new religious society. The date of their composition is not clear, though given that Velayuda Mudaliyar seemed to have some in his possession in 1867, we can assume that they were not all written in the last years of Ramalinga’s life.

Velayuda Mudaliyar, editor of the prior five chapters, did not contribute to the 1885 publication. His non-participation may indicate that he disputed the publication, as the poems of the sixth chapter would certainly undermine his goal to present Ramalinga as a conventional Shaiva saint. R. Venkatesan suggests that Ramalinga's "middle caste" supporters, which included Velayuda Mudaliyar as well as some of his financial patrons, were seeking to establish their position within established Shaivism. He argues that they therefore resisted the publication of verses that directly criticized established Shaiva practices and norms. ${ }^{27}$ The title page of the sixth chapter states that it was published at the request of two "honorable members" of Ramalingas "Society of the True Path." It states that "the goal of those who dare to publish this is to make it available for the general use of those of the Vadalur, that is Parvatipuram, almshouse. It is not for others." ${ }^{28}$ The editors seem to have been responding to some controversy, or at least sensitivity over the verses, by clearly stating that work was only for those in the organization left by Ramalinga. However, they also would post the book to interested buyers: "Anyone who wants the book can send the book price and postage costs by money orders 
to: ..." The volume was therefore both esoteric and freely available to anyone who could afford the somewhat extravagant price of three rupees and eight annas.

The title page lists the author of the work as "Ramalinga Swamigal." As a title, Swami indicates a high level of spiritual attainment and religious authority. When the 1867 edition of Tiruvarutpa $\bar{a}$ was nearing publication, Ramalinga explicitly directed his followers not to call him "Swami" in the publication, hinting at some controversy. ${ }^{29}$ It is no accident that this title appears on the sixth chapter of verses, which makes a strong claim to Ramalinga's extraordinary attainments. In this gesture we see a significant departure from the goals of the 1867 publication. If that earlier publication sought to establish Ramalinga in the lineage of Shaiva poetsaints, the publication of the sixth chapter cemented his status as a miracle-worker and vocal critic of established Shaivism.

Largely because of the poems of the sixth chapter, Tamils today often consider Ramalinga to be the latest in a line of Shaiva siddhas. Popular books that focus on Ramalinga's powers and status as a siddha reflect the contemporary popularity of both Ramalinga and the Tamil siddhas. ${ }^{30}$ Scholars follow suit, with Stuart Blackburn tracing a siddha tradition from Kannada Virashaiva poetry to Civavakkiyar to Ramalinga, and Raj Gautaman noting the debt Ramalinga's sixth book owed to the siddhas. ${ }^{31}$ It seems that Ramalinga had direct familiarity with Tamil siddha writings. In his 1882 biography of Ramalinga, Velayuda Mudaliyar wrote that Ramalinga could "recite the contents of the works of Agastia and other Munis," Agastya being a siddha whose authorship is attached to many works on medicine, alchemy, and magical rituals. ${ }^{32}$ People began to describe Ramalinga as a siddha soon after his death, if not before, a logical consequence of popular perceptions of Ramalinga as an alchemist and miracle-worker. In the first complete edition of his poetry published in 1892, the title page describes Ramalinga as a "divine, great siddha," a convention followed by subsequent editions. In the biography appended to that edition, P. Ramasami Mudaliyar writes that just prior to his disappearance, Ramalinga told his followers that his body would soon vanish, and he would become a siddha for forty thousand years..$^{33}$ Since at least 1899 , Ramalinga has been included in collections of siddha poems, such as Patinencittarkal Periya Nānakkōvai [The eighteen siddhas' garland of great knowledge]..$^{34}$

In his own writings, Ramalinga does not refer to himself as a siddha. He does, however, frequently claim to possess the siddhis, which is the basic criterion for inclusion among the siddhas. The 1885 publication is replete with Ramalinga's claims that he received miraculous powers and other boons from Shiva. These powers and boons include the acquisition of a golden body, the ability to raise the dead, divine ambrosia, the siddhis, and immortality. Although Ramalinga's closest followers hesitated to publicize the siddha elements of his writing, Ramalinga himself announces often and with no ambiguity his attainment of the siddhis. He credits Shiva with bestowing the powers on him: "You brought my heart to life, and gave me the boon of immortality. You gave me all the limitless siddhis. You 
gave me, a slave, your great compassion. Such is your way!" (3848). In describing the siddhis as a gift from Shiva, Ramalinga departs from classical yoga traditions, which consider the siddhis to be markers of ethical, physical, and mental accomplishments that are earned, not bestowed by god. Ramalinga's characterization of the siddhis as a gift from Shiva indicates his dedication to a bhakti framework that is less pronounced in Shaiva tantra and largely absent in classical yoga.

Ramalinga frequently juxtaposes his depravity and the siddhis, employing a further bhakti trope that highlights the greatness of the divine in comparison to human imperfection. In his poem "Perra Pērrinnai Viyattal," or "Amazement about the great boon that was received" (3842-3851), he consistently cites his moral deficiencies. "I'm an insignificant person. What can I do? I'm lower than a dog who roams around the bazaar" (3844). "I'm below everyone, more insignificant than everyone else. Who will be patient with my faults?" (3845). The answer to this last question is Shiva, of course. "There is no one as degraded as me, yet you raised me up to the amazement of everyone. You graced me with a golden body, an unblemished heart, complete knowledge, wealth, the powers (siddhis) capable of doing anything one thinks of, and great rapture. Oh lord without equal! I proclaim: such is your grace" (3849). In these poems, Ramalinga departs from tantric Shaiva narratives of the acquisition of siddhis, which stress the eminence of the recipient. ${ }^{35}$ An important consequence of Ramalinga's positioning of the siddhis in a bhakti framework is that he makes them compatible with human imperfection, effectively expanding their accessibility to all sincere devotees.

What are the powers that Ramalinga receives? He mentions a variety of extraordinary gifts: a golden body, perfect cognition, riches (presumably acquired through extraordinary means), and great joy. He describes Shiva's gift of ambrosia (amirtam), which he links to immortality (4960), eternal knowledge (4909), bliss (3693), freedom from bondage (3693), the Universal Path (3696), and clarity of mind (5489). Ramalinga considers immortality to be the most important of all of Shiva's boons, and he consistently emphasizes that he has transcended death. This claim was dramatically manifested when, in the last days of his life, he went into his residence, which he called "The House of Siddhi" (citti valākam), locked the door, and never emerged. His followers assert that he did not die. ${ }^{36}$

The list of Shiva's boons indicates that Ramalinga was drawing on diverse sources and traditions. His specific characterization of the siddhis evokes Shaiva tantric traditions more than they do classical yoga. The siddhis frequently appear in Shaiva tantric texts from the fifth to sixth century. ${ }^{37}$ This corpus of texts views the siddhis as instruments of amusement and enjoyment that are thoroughly worldly in their application and benefits. Rather than describing the attainment of siddhis through ethical purification and ascetic discipline as in classical yoga, tantric works outline mantra-based rituals for attaining siddhis, including immortality, the power of flight, and sexual enjoyment of women in "subterranean paradises. ${ }^{{ }^{38}}$ Ramalinga's account of the siddhis contains some of this tantric flavor. $\mathrm{He}$ 
describes them as "countless" powers that he commands "at all times in the world and the heavens" (4961). With the siddhis one can do "everything one can imagine" (3849). Ramalinga associates the siddhis with pleasure, worldly action, and play or sport, exclaiming to his reader that "the holy day when we play with the siddhis has dawned" (4906); he uses the siddhis to "dance in every world" (3692).

Others boons confirm this tantric influence and suggest other sources of inspiration. Ramalinga claims that Shiva "gave me a youthful, golden body that never perishes" (3869), suggesting Tamil siddha alchemical and medical influences. ${ }^{39}$ As we have seen, hagiographies of Ramalinga refer to his alchemical powers, and Navalar reported that Ramalinga himself claimed to be able to produce gold. Tamil siddhas are frequently attributed with alchemical powers, an attribution that is consistent with pan-Indian siddha traditions. ${ }^{40}$ The claim to have undergone a perfection of cognitive processes and to have received clarity of mind evokes classical yoga goals. Finally, "great joy" (3849) is a central promise of Tamil Shaiva bhakti. While it includes some of the resonances of material pleasure, it also points to a transcendent joy that surpasses the possibilities of materiality. Thus, Ramalinga described his extraordinary powers in ways that have precedence in Shaiva traditions that characterize much of Ramalinga's thinking: yoga, bhakti, tantra, and siddha.

An additional point of difference with yoga and tantric traditions, but more in line with siddha traditions, is that Ramalinga consistently links the siddhis to liberation. In the Yoga Sutras, Patanjali advises that the attainment of the siddhis is not the final stage of yogic accomplishment, but that one must be dispassionate toward the powers and go beyond them, pointing to the dangers of pride and attachments due to these "enticements of the gods." ${ }^{41}$ Somadeva Vasudeva notes that in Shaiva tantric traditions, the siddhis are associated with enjoyment more than they are with liberation. "When Śaiva religious activities are classified teleologically into the pair of those that are conducive to liberation (mokșa, mukti) and those that are conducive to experience or enjoyment (bhoga, bhukti), the latter goal is often synonymous with the siddhi." ${ }_{42}$

Ramalinga, however, generally describes the siddhis as a feature of liberation. He praises Shiva: "you destroyed the cruel bonds of illusion, karma and arrogance that afflicted me. You turned my heart into a holy temple; you gave me all the siddhis; you turned my body into a golden body, and fed me fresh ambrosia" (3866). Ramalinga regularly speaks of the acquisition of the siddhis alongside other soteriological accomplishments, suggesting their equality. "I realized that the state of Shiva (civam) is unified, and at the very moment I realized this, I reached a state of true understanding. And lo and behold, I received all the true siddhis, which are the fruits of devotion to the dancer in the hall of Chidambaram" (5499). While other Hindu traditions clearly consider the siddhis to be derivative or auxiliary to liberation, or even obstacles to liberation, for Ramalinga the siddhis are part of liberation, and the pleasures of the siddhis are consistent with the joy of liberation. 
Ramalinga's incorporation of the siddhis into a bhakti framework made the siddhis a powerful tool in his nineteenth-century context. He cannot take credit for this particular innovation, however. Rather, as David Shulman notes, Tayumanavar had similarly sought to integrate aspects of yoga and bhakti traditions about a century and a half before Ramalinga wrote his poems. Shulman notes that Tayumanavar was influenced by classical yoga and especially by medieval tantric yoga traditions that emphasize "magical transformation of the body and world in the direction of immortality, physical and psychic power, alchemical effects, and antinomian attitudes towards social order." ${ }^{43}$ Tayumanavar sought the siddhis and alchemical knowledge, and also yogic equanimity. He emphasized that the siddhis fall short of true realization, however, which he conceived as a state of mental control and contemplative tranquility. ${ }^{44}$ Ramalinga, unlike Tayumanavar, placed the siddhis at center stage and made them part of his soteriological goals. By lowering the intellectual and practical demands for the siddhis, he made their attainment a possibility for any sincere Shaiva worshiper.

What is missing from Ramalinga's claim to have received the siddhis, and from his specific description of the character of these powers, is any rationalizing sensibility that we saw at work among cosmopolitan reformers. His claim to possess powers was directly contrary to reformist rationalities that sought to locate the miracles of Hindu traditions in the past, and that recoiled at the attribution of extraordinary powers to any living person. As we will see in the next section, however, this does not mean that Ramalinga was in no way influenced by cosmopolitan discourses.

\section{RAMALINGA'S PROMOTION OF THE SIDDHIS: THE SOCIETY OF THE TRUE PATH}

By dropping yoga's demand that the siddhis can only be achieved after rigorous physical and mental practice, and tantra's demand for esoteric ritual knowledge, Ramalinga was able to introduce a community of devoted householders who would all possess the siddhis, most importantly, the boon of immortality. This democratization of the siddhis was consistent with other features of his teachings and reflected his vision for social transformation of his world. Here I examine Ramalinga's voluntary society and his promotion of the siddhis to Shaivas of a broad range of castes and classes.

In 1865, Ramalinga established the "Camaraca Veta Canmārka Cañkam," the Society of the True Path that is Common to All Scripture. ${ }^{45} \mathrm{He}$ conceived of his society as an organization that would embody his teachings, which he called the "True Path," and which would put those teachings into practice to effect social change. The society was at the center of a broad range of institutions and initiatives. An 1867 announcement states that the members intended to establish a number of branches that would be part of the society, including those specializing 
in medicine, textual study, service, development, ritual worship, law, and yoga. ${ }^{46}$ It is not clear whether the society successfully established these branches. They did, as we have seen, establish an almshouse in 1867 to enact this ideology of ritual giving. In 1872 they finished construction of a temple, the "Cattiya Nāna Capai" (Temple of True Knowledge), that housed an image of god as fire that they called "aruṭperuñjōti," “The Great Light of Grace." 47 The temple and almshouse served as the center of worship for the community during Ramalinga's lifetime, and they remain in use today.

The society had a formal, if loose, structure. Two fliers that announced the opening of the almshouse in 1867 give some indication of its organization. One was signed by "M. Appasamy Chetty, a member of the Society of the True Path, on the command of Chidambaram Ramalinga Pillai, head of the Almshouse of Unity." ${ }^{48}$ Membership seems to have been deliberately taken and recognized by others of the society. The second announcement was signed by the "Members of the Society of Unity," indicating that the society consisted of a group of members that acted in a concerted way. ${ }^{49}$ One of the few pieces of evidence that gives us detailed information of the society membership is a list of those who made financial contributions toward the establishment of a journal called "Canmārkka Vivēka Virutti [The Nature of the Wisdom of the True Path]." ${ }_{50}$ The list, dated from 1867, includes forty-nine names, their places of residence, and amount contributed. A variety of towns are named, most in the Pondicherry-CuddaloreVadalur-Chidambaram region, with little representation from Chennai. The caste composition includes a range of communities, including brahmans (Aiyars), merchants (Naidu, Chetty, Reddy), Mudaliyars, Pillais, at least one Muslim (Kadhar Sahib), and number of names with no caste marker, which may indicate dalit castes, such as Velayudam, Arumugam, and Arangasamy. ${ }^{51}$ It seems clear that at least to some degree, Ramalinga's society successfully transcended the caste distinctions that he attacked so forcefully.

Ramalinga declared himself to be the indisputable human leader of his Society of the True Path, stating that he was chosen by Shiva himself to spearhead a new movement. He writes of the public nature of this selection, where Shiva singles out Ramalinga as the special recipient of his grace in conspicuous public displays. He sings that Shiva "crowned" him "with all the world looking on," a clear gesture toward his leadership claims (4166). "All the flawless people of the world, they really saw this. He of the hall of the lord raised lowly me above the realm of words with brilliant light and gave me the nectar of grace" (4825). It is not quite clear who, precisely, Ramalinga refers to as witnesses to these acts of grace, and perhaps the ambiguity of this reference would allow any followers to consider themselves part of this audience.

Ramalinga's founding of a voluntary society appears to have been influenced by cosmopolitan models of religious organization. Ulrike Stark notes the proliferation of such associations in North India after the 1857 rebellion. These associations 
"emulated British models," allowing "educated Indians to actively participate in the grand 'project' of modernity." They advanced "a civilising project based on notions of individual morality and merit, civic participation, public service and social reform." ${ }_{52}$ Ramalinga's society embodied this sort of project, as an association of like-minded individuals who would implement his social and ethical vision of nonviolence, compassion, and social inclusivity. Individuals could join on a voluntary basis, in contrast to established Shaiva forms of inclusion based on lineage and caste. This elective society internalized important features of Western discourses of religion, namely, the notion that religion is a matter of individual choice; that religious communities should advance social change; an assertion that all worshipers, regardless of caste, have access to god; and the emphasis on personal conscience and ethics as central features of a religious community. ${ }^{53}$

Ramalinga's verses in the sixth volume of Tiruvarutpa emphasized compassion and nonviolence as central features of his society. Ramalinga reports that Shiva instructed him: "All those who have compassion are part of the True Path. Join with them here, come and enjoy, playing on the subtle path of good grace" (4163). Ramalinga makes nonviolence the central criterion for inclusion in his society, singing, "My guru [Shiva] directed me: 'Shun those who perpetuate killing; all others are part of your clan. You are the head of my clan, oh son! Act so that the Unified, True Path of Pure Shaivism, which destroys delusion, will flourish'” (4159). When Ramalinga condemns killing, he particularly has in mind meateating, asserting that Shiva told him that "those who perpetual killing and enjoy eating flesh are cruel people" (4162). He directs his followers to show compassion to meat-eaters, but also to avoid associating with them (4162). In defining the boundaries of his community through individual ethical behavior, Ramalinga departs from tantric and siddha paths that highlight technical skill and alchemical knowledge. He also departs from established Shaiva traditions of his day, which made caste a central criterion for community belonging and for religious authority. Ramalinga's community was ideally open to all, but because vegetarian and nonvegetarian diets have caste associations in South India, brahmans and vegetarian vellalars would have found it easiest to meet his dietary demands.

If Ramalinga's society shared the social and ethical objectives, and the form, of many cosmopolitan reform societies, his emphasis on the miraculous was a point of radical difference. Stark notes that voluntary associations in the period sought to advance scientific knowledge. The group that was the focus of her study, Jalsah-e Tahzib, described their first objective as undertaking "the necessary efforts in giving currency to useful arts and sciences," signaling their dedication to advancing scientific rationalism in Indian society. ${ }^{54}$ Ramalinga outlined a goal that directly challenged this rationalism: he based his leadership credentials on his possession of the siddhis, and he promised that those who joined his society would themselves acquire supernatural powers and initiate Shiva's physical coming to raise the dead to life. 
Ramalinga invites his followers to share in Shiva's grace and the siddhis through him. He describes a present world characterized by the proliferation of the extraordinary. "The light of grace is flourishing, the darkness of night is disappearing, my heart is overflowing, auspicious things are happening, a golden hue is everywhere, the woman who is the siddhis is mating" (3758). The siddhis are thus not just individual achievements, as in classical yoga or tantric traditions, but they are divine gifts that can be shared and enjoyed collectively. Ramalinga gives his own attainment of the siddhis an evangelistic imperative, emphasizing that Shiva favored him so that Ramalinga would carry Shiva's message to the world. "My father gave to me, a person of this world, the ability to see the entire world and all worlds. I will continue to pursue my path, making all beings join the society of the True Path" (5514). Indeed, here Ramalinga claims to employ the siddhis to recruit members to his society.

Ramalinga enticed his audience with promises that they, too, could receive grace and extraordinary powers from Shiva. He warns them of their impending deaths and offers his society as a path to immortality. "Thinking, I have honor and connections, you rejoice proudly here. You don't know the secret place. Haven't you heard the news that angry Yama, the god of death, is coming? Don't you think even a little bit about your relatives who have died?" (5573). In his poem “Tiruvuntiyār," "They Who Play the Holy Game," Ramalinga invites a companion to join in and "play the game." "Play the game of unti, chanting 'I saw my father, and attained the boon of immortality.' Play the game, chanting 'I can perform all the siddhis.' Play the game, chanting 'I gained liberation, and with that liberation I gained the siddhi of knowledge.' Play the game, chanting 'I am a siddha'" (4903-4904). He promises that playing the game will remove his listeners from the sorrows of the world and will deliver to them the highest powers imaginable.

What game is Ramalinga playing? It appears to have at least two components. One is conventional devotion to Shiva. "So that even people who are old with wrinkles will attain youth, so that the dead will rise again, the accomplished one, capable of depicting and doing everything, performs the dance of knowledge. This is the time he is coming! You shall attain this boon. Dissolving, the heart melting, your eyes widening, think joyously inside of god of the dance of compassion" (5583). Ramalinga suggests that his followers will receive Shiva's extraordinary boons through quite ordinary cognitive and emotional registers of Shaiva worship. "Thinking of him, experiencing him, your heart melting, full of love for him, your body wet with your tears ... praise him, people of the world, and you can live a life without dying" (5576).

However, according to Ramalinga, conventional modes of bhakti worship are not enough to secure immortality. One must also join Ramalinga's community, the Society of The True Path. "Oh you who are dear to me, come here and join the Society of the True Path! You can live, praised by the entire world of pleasures. You can obtain divinity and the siddhis, capable of all actions" (5580). Ramalinga 
claims that his society's True Path is the only one that will lead to immortality. "Take on bodies that are indestructible in the three times... People of the world, see that the auspicious opportunity is here and now. This is the time of the coming of my father, the great lord of the light of grace ... come and attain the True Path, the imperishable holy path" (5586). "People of the world, up until now, you haven't known the truth. Now follow the True Path of Unity and realize deep truths. Accept my father's grace, and you will receive the boon of immortality. You will have bliss" (5579). In a "confidential" circular dated April 27, 1870, Ramalinga tells his followers that their society will flourish once "we receive wisdom, and from that day on, our dead friends, relatives, neighbors, youth, children, sons and daughters, men, and women, all of them will be revived." 55 Ramalinga offers physical, bodily immortality not only to those who join his path, but even to their dead loved ones.

Ramalinga's promise of the siddhis to those who join him is consistent with the way that yoga, tantra, and siddha traditions have utilized the siddhis as enticements for centuries. ${ }^{56}$ Tamil siddha medical traditions today continue to search for powerful medicines that might bestow immortality, while tantric traditions detail techniques to bring the world under one's control for the sake of pleasure and power. Ramalinga follows these traditions, but he significantly reduces the threshold of expertise required, offering the siddhis through a relatively simple path of virtuous action, bhakti, and dedication to his True Path. This is consistent with his larger project of making the highest goals of Shaivism accessible to ordinary worshipers and of establishing a broad community of householders. To this end, he found an ideal organizational model in emerging voluntary associations, which brought together like-minded individuals who shared an ethical orientation and pursued their goals in concert. He was not, then, limited by a "traditional" orientation but drew liberally from a variety of teachings and models that were available to him.

\section{RAMALINGA'S CRITIQUES OF CASTE, SCRIPTURE, AND ESTABLISHED TRADITIONS}

In addition to his literary contributions, Ramalinga is probably best known today for his attacks on caste and established religious traditions. As we have seen in prior chapters, his early poems hinted at a critical attitude toward elite, exclusionary Shaiva practices. The sixth volume of verses gives explicit voice to these critiques and sets out his vision for an alternative to established Shaivism, one that would include a range of castes and classes.

It seems clear that Ramalinga was drawing on Tamil siddha traditions in formulating these critiques. Kamil Zvelebil describes the writings of the Tamil siddhas as "a protest, sometimes expressed in very strong terms, against the formalities of life and religion; rough handling of priests and brahmins in general; denial of the 
religious practices and beliefs of brahmanism, and not only that: an opposition against the generally pan-Indian social doctrine and religious practice; protest against the abuses of temple-rule; emphasis on the purity of character." ${ }^{57}$ Although Ramalinga does not single out brahmans for critique, he shares this siddha spirit of protest against elite practices. His attacks centered most on the non-brahman, vellalar institutions that dominated Shaivism; the scholastic traditions of those institutions; and the textual and ritual elitism associated with them. Ramalinga's attacks on social hierarchy, and his emphasis on siddhis and immortality, clearly indicate that his central ethical positions were influenced by siddha traditions. It is likely that contemporary debates also informed Ramalinga's critiques, as a variety of colonial, reformist, and missionary leaders engaged in acrimonious exchanges about caste, scriptural authority, and ritual practice.

In these poems, Ramalinga attacks religious traditions that were prevalent in his day, distinguishing his society from established traditions. He most often refers to other religious traditions as "matam" or "camayam," terms that are most often today translated as "religion." ${ }^{8}$ When he uses these terms, he does not have in mind a group of world religions and does not describe a comprehensive phenomenon. Thus, the term "religion," taken in the modern sense, to translate his use of matam or camayam, is misleading. I will leave the terms untranslated or occasionally translate both as "tradition." Ramalinga uses these terms to refer to specific traditions that were active around him or that he knew through Tamil literature. He never refers to his True Path as a matam or camayam, consistently calling it a path, a "neri." He describes matam and camayam only in negative terms, pointing to "the troubles of matam and camayam" (3319), "a sinful path of camayam and matam" (3696), "nauseating matam" (3709), and "foolish matam" (5592).

Ramalinga speaks of all religious traditions other than his own as matam and camayam. He writes that Shiva told him that "all the heads of matam, such as Brahma, Shiva, Vishnu, the other gods, the famed Buddha and Mahavira, they are just a gang of small children, who appeared in the heavens, saw a little bit of god's light, and played around in heaven and earth like they're drunk" (4178). Here Ramalinga's conception of religious community is not derived from a World Religions discourse, but draws from a Shaiva literary world in which Shaiva traditions vied for preeminence with Vaishnava, Buddhist, and Jain traditions, as described in the Tèvāram and Periya Purānam. His critiques of a range of traditions reveal an attitude of exclusivity that is contrary to common perceptions of Ramalinga as an ecumenical unifier.

Ramalinga defines his path against Buddhist, Jain, and other Hindu paths, but I have not found references to Christianity or Islam in his writings. This does not mean that he was unaware of these traditions, or even that he was not influenced by them. Islam had a significant presence in his region at the time he wrote, and the impact of Christian missions was extensive. However, as I have argued throughout these pages, it is difficult to posit specific influences of these traditions 
in the absence of clear evidence. His conception of the religious landscape of central Tamil Nadu was shaped by the traditional Tamil Shaiva literature that he knew, including the canonical bhakti works of the Têvāram and the Periya Puranam. We might posit that the world that he lived in was distinct from the world that he described in his writings. This, however, was not the case. His writings on hunger responded to an environment of food shortages and even famine. Likewise, his writings on caste and the failings of other traditions express his concern for the society in which he lived. His most sustained critiques refer to specific aspects of Hindu traditions that were influential in his time and place. Why he chose to forgo direct reference to Christianity and Islam in his writings is something of a mystery. In any case, this sets him apart from Navalar and from other cosmopolitan reformers of his day, for whom Islam and especially Christianity provided important points of orientation in their redefinition of Hindu traditions.

For the most part, when Ramalinga refers to other, competing religious traditions, he has in mind Hindu concepts and practices, indicating that his primary foils are Hindu traditions. He distinguishes his "True Path" from these opposing traditions. "Oh lord, you revealed to me that all this is child's play: communities of camayam, bound together by their excess karma; their traditions of learning; the paths set out in those traditions; their images of deities; and their gods. . . . The traditions of learning that talk about the four castes (varuna), the stages of life (āciramam), established practices of conduct (ācāram), etc., all this is child's play" (4173-4174). The language of varuna, àciramam, and ācāram confirms that Ramalinga's criticisms are directed to the exclusionary, caste-based, elite practices and texts of Hindu traditions. Thus, he frequently links matam and camayam with cāti or caste. He addresses Shiva: "You taught me long ago that the rubbish piles of shastras, which distinguish many paths according to caste and camayam, are worthless. I realized this truth only today, through your love and grace. I am now on the path of unity which is praised by the learned" (5515). He condemns a variety of Hindu practices and traditions as "possession-dancing," including "caste, lineage, camayam, matam, initiation, caste conduct" (5508). This linking of caste with matam and camayan indicates that Ramalinga's critiques were directed toward Hindu traditions, most pointedly the Shaiva traditions of the mathas that dominated religious intellectual life in the Kaveri Delta. However, he was not an advocate for ritual practices and theologies associated with low-caste communities. His characterization above of elite elements of Hindu teachings as "possession-dancing," a practice associated with lower castes, reveals his own rejection of low-caste practices.

Ramalinga blames the proliferation of gods and sects for confusion, conflict, and death. He condemns "those who think there are many gods, those who profess many ways to reach god, those who exclaim the various, false scholarly disciplines, those who admire the many false traditions" (4726). His frequent references to religious controversy appear to reflect his historical milieu, in which conflict was a 
major feature of interactions between traditions. He writes that Shiva told him that "the beings of the vast earth, they don't realize that all the various religious traditions are crazy spirit-possession and child's play. They perpetuate all sorts of division and conflicts everywhere. They perish, their lives wasted" (3677). Ramalinga claims that Shiva told him that "a destructive path, consisting of the many religious traditions, has thus far prevailed. People of the world haven't known the refined path, and they have kept dying. Until now, they have been living in darkness" (3696). The proliferation of false traditions leads to a variety of social ills and, ultimately, death.

For Ramalinga, there is nothing to redeem, reform, or save from these traditions, so he pushes for their elimination in favor of his True Path. Shiva urges Ramalinga: "you go and steer them away from the diseased path. Lead them to the excellent path, the Pure True Path, which is the public path that bestows the heavenly, fresh ambrosia" (3696). Ramalinga's True Path is not an elite path that is limited to those of particular castes or with particular intellectual achievements, but it is a "public path" accessible to all. Shiva grants extraordinary boons only to those on Ramalinga's path, so Ramalinga presents the choice between his path and established paths as a choice between life and death. "Oh people of the world! ... Why will you not accept the great boon of immorality? .. . Do you take joy in disease and old age?... There is just one excellent, true path. Look, it destroys disease, old age and death. Know this: in this very birth, you can achieve eternal life. You will quickly receive the highest bliss" (5600). As we have seen, Ramalinga even presents his potential followers with the prospect that their adherence to his teachings will lead Shiva to appear in Vadalur and raise the dead. Ramalinga's aspiration for his path was that it would transcend conflict and division between people, and usher in a new age of harmony and eternal life.

In addition to his attacks on caste and established traditions, Ramalinga also criticizes the elite texts of Shaivism, the Vedas and Agamas that reformers like Roy, Saraswati, and Navalar extolled as the basis of a reformed Hinduism. He is not always dismissive, at times writing that the Vedas reveal the truth of Shiva. For example, he calls Shiva "the god of Chidambaram who is praised by the Vedas as unity and diversity" (5510); "the highest of the jewels of the four Vedas" (3693); and the "light which is the apex of the greatness of the Agamas" (3700). However, just as often Ramalinga advances trenchant critiques of these texts. Shiva tells Ramalinga: "I'm telling you: the extant Vedas and Agamas are deceptive. If you see that they are false, both at the level of the meaning of words and as literature, then the truth of the Vedas and Agamas will be clear to you: you'll realize that the Vedas and Agamas, famous throughout the world, are lies" (4177). The problem, it seems, is not that canonical Hindu works are wrong in some fundamental way, but that they are mysterious and difficult to understand, and therefore mislead people and create conflict. "You engage in useless debate about the Vedas and Agamas. You don't know the fruit of the Vedas and Agamas. They speak mystifyingly about the 
truth which is in plain view. What use are they?" (5516). In an interesting reversal of the elite character and audience of Hindu canonical works, Ramalinga calls the study of the four Vedas, the Agamas, and shastras "bazaar education," contrasting this with his Pure True Path, which teaches the "knowledge of immortality" (4955). Again, the target of his criticisms are elite Shaiva traditions represented by the mathas in his milieu, the same traditions vehemently defended and promoted by Navalar. Ramalinga mocks "you great ones who think themselves greater than the Great One, you provoke conflicts, dirtying yourselves. You quote all sorts of false texts, taken from various traditions, and shout 'My God, My God, not realizing that there is only one God. What will you do when your material body dies? You don't know the way to make the fragile body immortal" (5570). According to Ramalinga, the danger of choosing any path that emphasizes textual learning is death itself. It is perhaps for this reason that Ramalinga dropped "Veda" from the name of his society in 1872, suggesting that his rejection of textual elitism increased toward the end of his life. ${ }^{9}$ In his critiques of texts, he never mentions the writings of the Tamil Shaiva saints, to which, as we have seen, he owed a great debt and in many ways used as a model for his own writings.

Ramalinga asserts that Shiva's grace and immortality could be gained only through direct, personal experience of Shiva, not through the Vedas and Agamas. He describes encounters with Shiva in sensory, and especially visual, terms. This assertion is consistent with his claims that he had frequent, close interactions with Shiva in the form of conversations, physical encounters, and direct sightings. After dismissing canonical texts as "child's play," Ramalinga reports: "You, my true guru, declared to me, open your eyes!" (4174). This contrast of the eyes with texts is a common refrain in his poems. "People speak about various treatises, from Vedagamas, Puranas, and Itihasas, to magical texts (intiracalam), they think that only those texts that confuse are trickery. Oh jewel, wise preceptor, catcher of my heart, you told me, 'my son, you must realize that all texts are trickery; view all activity with the light of my grace" (4176). Ramalinga equates esteemed works of Hindu traditions, the Vedas and Agamas, with magical texts that most orthodox Shaivas would view with suspicion. Ramalinga invites all listeners to join his society, where one can find truth by "viewing" all things, illuminated by Shiva's light.

Ramalinga described such encounters with Shiva in physical terms, not as interior or imaginative visions. He did not limit these encounters to individual interactions. In a circular addressed to everyone with some connection to his society, he announces that Shiva will appear before them all together. He instructs that they should not cremate their dead, but bury them. "Have complete faith that the dead will be resurrected and will return to us. Don't feel sorrow or cry out loud, but keep the god of Chidambaram in mind." He warns his audience to cease performing any rites for the dead, and he promises that if they do what he says, then Shiva will appear in the almshouse at Parvatipuram and will instruct them how to develop the society and the almshouse. Shiva will at that time resurrect those who belonged 
to the society. He will also resurrect others, even those who opposed the society, but they will not be allowed to join the society. ${ }^{60}$ The price for immortality is in this case not insignificant, as the rejection of mortuary rites would mark a radical break from established community norms. The rewards of this break are likewise immense. By rejecting textual learning, Ramalinga also spurned the authority of Shaiva traditions of learning that favored high-caste communities embedded in positions of power. This rejection was consistent with other aspects of his teachings, which clearly display his sympathies with the poor, the hungry, and ordinary worshipers. What he required from his followers was not a high-caste birth or technical knowledge, but the courage to resist social and ritual conventions.

The sources that inspired Ramalinga's Society of the True Path appear to be varied. His juxtaposition of social critique with claims to miraculous powers strongly suggest the influence of siddha writings. At the same time, the organizational structure of his voluntary society does not appear to have been drawn from siddha models. As T. N. Ganapathy observes, “The songs of the Tamil Siddhas do not show any trace of collective thinking; the Tamil Siddhas are not system-builders. . . They relied only on the individual's effort for the attainment of liberation." ${ }^{61}$ Likewise, Eleanor Zelliot writes of bhakti poets that "no specific social movement for an egalitarian society arose from the bhaktas." 62 Siddha and bhakti poets wrote as individuals and did not advance alternative social configurations. Ramalinga, on the other hand, founded a community based on siddha modes of critique and claims to immortality. It is likely that in this he was influenced by new models of religious community that developed in cosmopolitan India through engagement between European and Indian traditions.

We should not, though, describe Ramalinga's Society as a "mixture" of tradition and modernity, with siddha traditions contributing traditional, magical features and Western models providing a modern form of community. The sources of influence are too complex, too "entangled," to sustain such a simple account. In many ways, my discussion so far is already an oversimplification of Ramalinga's sources of influence. It is clear that siddha traditions in his time were in flux, with the publication of new compilations, composition of new works, and redefinition of siddha ideals as representing a monotheistic, Protestantized Hindu past. The pedigree of his claim to be able to raise the dead is unclear, but it does suggest the possibility of Christian influence. It is also likely that Ramalinga was more familiar with voluntary societies that were burgeoning in urban centers under Hindu and Muslim leadership than he was with associational culture in Europe. This is to say that in Ramalinga's time, siddha works were not "purely" Shaiva, and voluntary societies in India were not just "Western." To speak in terms of the encounter of two distinct societies, one modern and the other traditional, oversimplifies the complex webs of influence and interactions that characterized Ramalinga's world. It also discounts the creative potential of Shaiva traditions. What we can say, I think, is that Ramalinga's vision was modern, because it participated in the most 
important debates of his day, presented new configurations of community, anticipated future trends, and envisioned a future that motivated his followers to work to transform their society.

\section{THE “HERE AND NOW” OF RAMALINGA'S PATH}

Ramalinga's poems of the sixth volume are characterized by a heightened sense of immediacy. He focuses on the present, consistently emphasizing the newness of his path and his break from prior traditions. He celebrates this newness, something that set him apart from reform thinkers who imagined their projects as a return to an idealized past. Ramalinga hoped that his society would destroy the old and would usher in a new age. This gave his writings an urgency, even an apocalyptic character. In these poems, a distinct human audience comes into focus. While he addressed his earlier poems to his own heart or to Shiva himself, in these later poems he frequently addresses present and potential followers, the people of the world. His stress on the importance of the here and now, and his heightened concern to speak to a human audience, mark his teachings as modern in the sense that I have been using the term. That is, his vision was timely, broke from the past, addressed current challenges, innovated, motivated his followers to transform their world, and anticipated future directions for Hindu traditions. Like other aspects of his teachings, his sense of time, place, and audience drew from a variety of influences, Indian and Western, and it also displays elements that appear to have been Ramalinga's own innovations.

One of the primary distinctions he makes between his path and other traditions is that his is new and timely, and others are old and past. He attributes his ideas to his ongoing dialogue with Shiva. "Oh unmatched Nataraja, my precious teacher. You said, 'the multitude of paths appeared, lacking good qualities, and some disappeared. People of the world joined them, and lived in ignorance and distress. My son, this is the holy path, the path of grace that destroys distress and creates all good things. Strive to establish the wisdom of this public path which enables one to drink the cool ambrosia"” (3698). Ramalinga's task is to destroy past tradition, especially those elite traditions that valued caste distinctions and textual authority. He offers instead a "public path" that is accessible to everyone. He is keenly aware of the monumental challenge he set himself, given the power of established Shaiva institutions and the embedded character of caste and ritual practices. His alliance with Shiva is necessary - it is only Shiva's miraculous intervention that is capable of bringing about such an epochal shift, away from the troubles of caste, religious conflict, and death toward a universal community that enjoys immortality. He makes frequent reference to the transformative, miraculous character of the "cool ambrosia" that Shiva gave to him, describing it as "fresh" or "new" (3866, 5572). Given the persistence and pervasiveness of caste and religious hierarchies, Ramalinga could perhaps only envision the concrete realization of his teachings 
in miraculous terms. Victory would require the siddhis, ambrosia, and the direct intervention of Shiva.

Ramalinga spoke of Shiva's appearance in concrete spatial terms. He directed his followers to bury their dead in anticipation of their revival when Shiva appears at Parvatipuram. Such specific references to Shiva's physical return are consistent with his early poems, which provide precise detail of his encounters with Shiva. He promises members of his society that they will gain the same sort of direct, physical access to Shiva. "This is indeed the auspicious time when my matchless father is coming to the Northern Chidambaram which is famous as Cittipuram of abundant light. He comes in order to perform the five functions of god which are just a trifle to him, and to establish himself in me, who am overjoyed at his refuge" (5575). Ramalinga refers to the area of his temple and almshouse as "Northern Chidambaram," and "Cittipuram," the "town of the siddhis," is the place of his residence. In promising the imminent arrival of Shiva and the raising of the dead, Ramalinga was offering a narrative of hope for an extraordinary new stage of society.

Another spatial dimension of his narrative is his assertion that Shiva appears on the "street." "Oh people of the world, you wander aimlessly, valuing caste, dogma, sects, noisy doctrinal debates, and disputes over lineage. Your wandering is useless, it is destructive and ugly. Stand in the good path of justice. The dancer is the only lord. The play (vilaiyattal) of grace and light is occurring on the street. I call out: the right time has come" (5566). The "play" of grace and light is a clear reference to Shiva's activity, which is often described as a form of play, as in the popular text Tiruvilaiyātal Purānam [Divine play], which narrates sixty-four episodes of Shiva's activity. Ramalinga insists that Shiva's play is "on the street," in public for all to see, to experience, to access. This provocative imagery of Shiva in the street distinguishes Ramalinga's vision from that of traditions which located Shiva in obscure, elite textual knowledge, or in temples that limited access to particular caste communities. He draws on broader South Asian conceptions, where the street carries the resonance of a public space that does not exclude based on caste. Chakrabarty describes the street, the bazaar, and the fair as paradigmatic spaces in South Asia that are "outside" private spaces of regulation and control. This public space is "exposed. . . . It is not subject to a single sense of (enclosing) rules and ritual defining a community." The street is marked by unfamiliarity, danger, potential and possibilities. Because it is a public, accessible space, it "provides a venue for linkage across communities." ${ }_{33}$ Ramalinga's announcement that Shiva is available on the street highlights his accessibility. Ramalinga's public Shiva contrasts sharply with worship at established Shaiva temple centers like Chidambaram, which in Ramalinga's time excluded people of certain castes. For Ramalinga, Shiva's revelation is available to everyone, not limited and controlled by a Shaiva elite.

In at least one verse, Ramalinga plays on this distinction between public and cloistered manifestations of Shiva. The term "potu" designates "public" things, but 
it is also the name for the inner chamber of Chidambaram, one of the most highly controlled abodes of Shiva, which in Ramalinga's time was not open to worship by dalit castes. Ramalinga sings, "I realized that all living beings are equivalent to that revered hall (potu) where you perform your sacred dance. . . I sing these public songs [potuppātțu, which can also mean 'songs of the Hall of Chidambaram'], so that the tender sprouts of the pure True Path flourish" (5426). By asserting that all living beings are revered sites of Shiva's sacred dance, Ramalinga universalizes the private space of Chidambaram by extending it to all the world's beings. This move epitomizes the accessibility of his True Path: he opens up the sacred hall of Chidambaram to all beings.

Ramalinga not only writes of the "here" of his revelation but also of the "now." He speaks to his listeners with a sense of urgency. "See that this is the time when our god will rise up and grace the world, in order to quickly destroy all the foolish matam which brings no benefits to the world, and in order that the unique True Path, which is without errors, is established everywhere. Like people sleeping who wake and rise up, all the dead are appearing and rising up. This has already begun. Come quickly and learn!" (5592) He urges people not to delay from joining his path, cautioning them to put their doubts aside. "Don't wonder, 'what is the time of clarification, when god of the light of grace will come, so that the entire world will rejoice and attain bliss for immeasurable time?' O people of the world, this is that luminous time, when the dead will rise" (5584). The danger of delay is death, which can strike at any moment. "If you delay even a little bit, thinking 'we'll come to that later, then the great sin that is death will come. Behold! You can't delay that, even a little bit. Except for the members of the Society of the True Path, there is no one in any world who is capable of fighting against that and delaying it" (5599).

Ramalinga appears to acknowledge the radical character of his claims, and he urges people not to doubt his words. "Our kin who live in the four directions, don't despise my words as lies" (5532). He reassures his audience that Shiva's coming is imminent, and the immense benefits of joining his society will be immediate. "Don't despair, wondering which day will our father come, he who rules all? Don't worry at all. I told the truth directly: he will appear on this very day and come" (5533). Those who join his path will immediately enjoy its benefits, including the siddhis. "All the glittering sects and religions are full of lies. Don't join them. Know that god is one. Know and worship the dance of the hall. Today all the siddhis will truly come [to you]" (5595). Ramalinga's promises were not general or vague, but specific as to the place and time of Shiva's appearance: Parvatipuram today, or at least in the very near future. Ramalinga's sense of time was not the homogenous time of Western modernity but a sense of the special nature of the present. His emphasis on the conquering of death was itself a conquering of history, an abolishing of the progression of life and death.

The immediacy of Ramalinga's message is accentuated by the emergence of a clear, human audience in these poems. Instead of addressing Shiva, or his own 
heart, as he does in his earlier poems, here he speaks to his contemporaries, those who are in his society and especially those whom he asks to join him. He speaks to "those close to me who are spread in the four directions" (5532), and he asks "you are dear to me, come here and join the Society of the True Path!" (5584). Most often, he addresses "people of the world" (ulakir), signifying a broad, general audience of listeners not distinguished by caste or class. He often couches this form of address as a sort of warning, describing his audience as "people of the world that deludes" (5598) and "people of the world of unbearable strain" (5569). He invites "you of this earth" to join him at Cittipuram (5574). His effort to address a broad, inclusive audience is consistent with his goal to create a truly universal community.

Ramalinga's invocation of "people of the world" has parallels in North Indian devotional literature. Christian Lee Novetzke notes the Marathi poet Namdev's use of "loka" to address a broad audience of listeners. He describes this "loka" as a "public," asserting that such referential practices seek to unify an audience "unmarked by caste, class, or gender," but they also divide, as "the creation of shared publics is also always a creation of differences between different publics." ${ }_{4}$ Ramalinga's invocation of people of the world, equivalent to Namdev's "loka," performs similar work, even if the sense of a public is so diffuse it seems difficult to define as such. He does, however, clearly divide those who join him and those who do not. Members of his society will be blessed with immortal life, and those who reject his teaching will be relegated to death. Ramalinga writes that Shiva told him: "Those who kill beings and eat flesh, they are not close to us. They are outcasts. Until they approach your desirable true path, do no more than dispel their hunger. Don't sympathize with them or speak courteously to them. Don't give them friendly assistance. This is my command" (4160). Contrary to his professed ideal to establish a universal society, Ramalinga's writings enforce divisions among the "people of the world" whom he addresses.

Ramalinga's sense of place also has precedents in Tamil Shaiva bhakti and siddha traditions. Bhakti poet-saints such as the authors of the Têvāram sung at length about Shiva as a living presence at local temples and towns. Siddha poets spoke of the street as a site of divine "play," not of public impurity. Pattinattar wrote of Shiva: "He walked the street in the habit of a mendicant-devotee, searched and found me and said: 'Share your alms with me.' Hearing this I fell at his feet." ${ }^{6}$ Pampatti siddha links his anti-caste stance with accessible, public spaces.

We shall kindle the fire in the rift among castes

We shall plant our staff in open market places

We shall play and dance on the crossroads and in the streets

We shall establish friendships in undesirable houses ...

This is what you do and say o dancing snake. ${ }^{66}$

Ramalinga's sense of the "here" is thus attested in the Shaiva poems that influenced him most significantly. 
Ramalinga's sense of time is more difficult to trace. Some aspects align with notions of time and history in Western modernity as described by Reinhart Koselleck. These include "the knowledge that one is living in a period of transition in which it becomes harder and harder to reconcile established traditions with necessary innovations." ${ }^{7}$ Ramalinga's rejection of the established Shaiva traditions and deliberate embrace of change mark him out as "modern" in Koselleck's terms. Likewise, his desire to destroy all prior traditions and establish a new community conforms to a "true present" in Marshall Berman's summary of Paul de Man's formulation. The "full power of the idea of modernity lay in a 'desire to wipe out whatever came earlier,' so as to achieve 'a radically new departure, a point that could be a true present." ${ }^{68}$ Or, his rejection of past community and his aspiration for a future with a radically different configuration of society conforms to S. N. Eisenstadt's assertion that the redefinition of communities is a central aspect of modernization. This is especially the case for the consideration of belonging to wider, nonlocal communities, such as Ramalinga's voluntary society open to people of all castes and classes. ${ }^{69}$ In other ways, though, he departs from Western modernity's sense of time. He displays little sense of the openness or changeability of the future; of the "nonsimultaneity of diverse but, in a chronological sense, simultaneous histories"; or of historical perspective..$^{70}$ Most importantly, for Ramalinga, divinity pervades time, and in his claims to immortality, he contends that death, probably the greatest marker of time, can be overcome, departing from a modern Western insistence that rationality should prevail in the flow of history.

Ramalinga's modernity, however, should not be denied or confirmed through establishing his departures from, or alignment with, characteristics of Western modernity. Instead, his project was modern because it exhibited an acute awareness of contemporary challenges; it responded to those challenges in innovative ways; it sought to transform the world; it was influential; and it anticipated future directions of Hindu traditions. Ramalinga's sense of time and place challenged Shaiva notions that regulated community based on caste, and he attacked past traditions in order to open up space for new possibilities. The newness of his vision is not undermined by the presence of divinity or the siddhis, or the promise of immortality. These features are essential to his project, and their removal would not have made his project more modern. The whole package was modern, and the sense of the miraculous was central to that modernness, in the way I have defined it here. Ramalinga's authority rested on his claim that he had direct experience of Shiva, and that Shiva granted him the power to perform miracles. He enticed followers by offering them the promise of the siddhis and immortality. His insistence that Shiva was in the here and now reassured his audience that they, too, could enjoy the fruits of Shiva's grace. These aspects of his teachings were not anachronistic but spoke to the most vital concerns of his time, and presaged the emergence of later expressions of Hindu traditions. By considering the modern apart 
from a list of features that describe Western modernity, we can include even these most enchanted aspects of Ramalinga's teachings as part of the narrative, or more accurately narratives, of the emergence of modern Hinduism. The timeliness of Ramalinga's message demands that we do just that.

\section{CONCLUSION}

Ramalinga's claims and promises of miraculous powers and immortality drew on prior Tamil siddha traditions. Testimonies about his life and disappearance followed narratives of the extraordinary exploits of gurus, yogis, and siddhas that have filled Hindu literature for millennia. Those traditions of yoga, or of the siddhas, are not static but are ever-changing, and Ramalinga was very much a siddha of the middle decades of the nineteenth century. He drew from a range of contemporary sources in imagining a voluntary society that would embody this extraordinary promise, which he hoped would respond to contemporary challenges in the world around him. His was a period of radical change, when colonial and especially missionary networks and institutions were increasingly providing ideologies and avenues for social egalitarianism. Within this context, he celebrated the most accessible features and most egalitarian teachings of Shaiva traditions. $\mathrm{He}$ considered the possibility of the miraculous central to this project. Most importantly, he gave the miraculous a communal character, founding a society open to all that would enjoy Shiva's extraordinary boons. He thus offered an organized alternative to both established Shaiva traditions and new expressions of reform Hinduism that were taking shape in the cosmopolitan centers.

When we consider a figure like Ramalinga to be crucial to the story of the emergence of modern forms of Hinduism, we challenge narratives that insist that Western rationality is necessary to all expressions of modernity. Notions of modernity need not only entail the emergence of rationality. After all, religion continues to be a major force in our world, and it shapes this world in crucial ways. We can describe Ramalinga's teachings as modern without having to overlook his emphasis on divine intervention, his promise of the siddhis, or his claim to have become immortal. Instead of parsing his message into "traditional" and "modern" aspects, we should rather take his message as a whole, one that achieved such relevance and influence that it invited criticism from powerful Shaiva leaders, motivated worshipers to action, and presaged future directions that a variety of Hindu traditions would take.

If we accept Ramalinga's project as integral to the transformation of nineteenthcentury Hinduism, it becomes clear that we need to expand our historiography of modern Hinduism to include a number of features that are more commonly assigned to past "tradition." We should consider Ramalinga's celebration of the miraculous, embodied in an egalitarian society, to be as modern as the Hindu reform pursuit of Protestant rationality. Ramalinga's promise of Shiva's appearance 
as a living, breathing, tangible god in the here and now inspired audiences of his time as effectively as did the Hindu reform emphasis on an abstract, monotheistic deity. Moreover, Ramalinga's insistence on the possibility, and indeed the necessity, of direct experience of Shiva, and his critique of elite texts and rituals, responded as well to the challenges of his day as did the reform Hindu insistence on the textual authority of the past. Ramalinga's powerful juxtaposition of accessibility, egalitarian community, and the miraculous presaged future directions of Hindu traditions as much, if not more, than did the elite textualism of reform Hinduism.

When we better understand Ramalinga's view of history, the misnomer of calling him a "reformer" becomes clear. He was not interested in reforming established Shaivism in the confidence that human effort can effect a rationalization of established religious practice and theology. He rather professed revolution, seeing his own role as the executer of Shiva's desire to destroy established traditions and establish a radically new community. Thus, Ramalinga was much more a siddha than he was a reformer. He was a critic who pushed the boundaries of the community he grew up in and the larger Shaiva community that dominated religious life in central Tamil Nadu. Ironically, then, his rejection and transcendence of Shaivism itself had a Shaiva siddha character. He articulated an alternative vision that gave ordinary people hope that they, too, could experience the miraculous in their local place and time. The timeliness of his message of the accessibility of the divine, with its critique of caste and elitism, spoke to the hopes and ideals of people across castes and communities. 